\title{
PRAKTYKA ŻYCIA DUCHOWEGO W UJĘCIU O. STEFANA KUCHARSKIEGO (1595-1653)
}

O. Stefan od św. Teresy Kucharski, karmelita bosy, Polak, żyje w latach 1595-1653. Pozostawił po sobie liczne traktaty i konferencje o treści ascetyczno-mistycznej. Wszystkie one dotąd pozostają w rękopisach. Najważniejsze z nich, a zarazem - jak się wydaje - w całości przez autora opracowane, są następujące: „Baranek Wielkanocny” - traktat o pełnym przyjmowaniu Chrystusa w Eucharystii, liczący 65 kart, Prakty$k a$ ćwiczenia się $w$ abnegacji” - kart 39, oraz: „O gruncie pokory $z w a-$ nej nic" - kart 15. Dwa ostatnie traktaty podają naukę na temat wyrzeczenia. Warto jeszcze wspomnieć zbiór konferencji związanych z rokiem liturgicznym ${ }^{1}$.

O. Stefan jest niewątpliwie jednym z mistyków karmelitańskich w Polsce. W jego nauczaniu, zresztą $w$ dużej mierze oryginalnym, można spotkać pewne powiązania z mistykami z północy, a także ze św. Janem od Krzyża. Zostało ta wszystko ukazane w monograficznej pracy na temat o. Stefana i jego działalności pt. „Działalność o. Stefana od św. Teresy Kucharskiego na rzecz recepcji św. Jana od Krzyża w Polsce”. W tym artykule zawarta jest zasadnicza część tej pracy, a właściwie dwa rozdziały z drugiej części, które pozwalają wystarczająco zapoznać się z doktryną głoszoną przez o. Stefana i wyrobić sobie zdanie na jej temat.

Wydaje się koniecznym podkreślenie, że o. Stefan nie tyle jest teoretykiem, co praktykiem i kierownikiem duchownym. Stąd tytuł „Praktyka życia duchowego" w jego ujęciu. Praktyka życia duchowego, którą autor proponuje, zawiera dwa nurty wzajemnie się przenikające, mianowicie: wyrzeczenie się starego człowieka i przyobleczenie się $\mathrm{w}$ nowego człowieka.

1 Istnieje kilka zbiorów rękopisów. Będę je cytował w następujący sposób: przy pierwszym powołaniu się na źródło podaję jego nazwę oraz oznaczenie zbioru, z którego pochodzi, przy czym: Wes rkps oznacza zbiór znajdujący się u Karmelitanek Bosych w Krakowie, ul. Kopernika 44; Łobz rkps oznacza zbiór będący w posiadaniu Karmelitanek Bosych w Krakowie, ul. Eobzowska 40; Ossol. rkps 1246 oznacza zbiór Ossolineum; Czerna AP oznacza zbiór z Archiwum Prowincji Karmelitów Bosych, będący w Czernej. Następnie w nawiasie umieszczam skrócone oznaczenie, stosowane przy kolejnych, dalszych powoływaniach się na źródło i zbiór. Istnieje także jeden rękopis w Bibliotece Kapitulnej w Sandomierzu, lecz nie cytuję go. 


\section{A. WYRZECZENIE SIE STAREGO CZEOWIEKA}

Zjednoczenie z Bogiem wymaga od człowieka pełnego wyboru Boga, całkowitego przylgnięcia do Niego. Człowiek, który pragnie zjednoczenia i chce wybierać jedynie Boga, odnajduje w sobie liczne przeszkody. O. Stefan ujmuje je pod jednym pojęciem - „stary człowiek”. Istnieje więc, jeśli się chce dojść do zjednoczenia, konieczność wyrzeczenia się starego człowieka. O. Stefan, mówiąc o starym człowieku, precyzuje to pojęcie. Pisze także na temat samego wyrzeczenia, jego zakresu i sposobów.

\section{Stary człowiek}

W niezwykle ciekawy sposób, o. Stefan kreśli sylwetkę starego człowieka. Treść tego pojęcia ukazuje $\mathrm{w}$ „Cwiczeniach na same dni uroczyste Narodzenia Pańskiego". W tej konferencji mówi o narodzeniu się człowieka z Boga i znalezieniu Narodzonego w sobie. Dokonuje się ono zazwyczaj w długim okresie czasu i przebiega boleśnie. W człowieku bowiem istnieje wiele przeszkód utrudniających mu narodzenie się z Boga. Zanim dobrze i doskonale Bóg zamieszka w człowieku, zanim on dojdzie do pełnego zjednoczenia z Bogiem, przeszkody te, tzn. stary człowiek, muszą być gruntownie zniesione i wyniszczone ${ }^{2}$.

W jaki sposób stary człowiek zamieszkał w człowieku? O. Stefan twierdzi, że każdy człowiek przychodzi na świat czysty. Przez takie ustawienie sprawy autor nie neguje faktu grzechu pierworodnego, raczej go zakłada. Człowiek jest więc na początku jak czysta tablica, na której nic jeszcze nie napisano, czyli wolny od złego i dobrego, a tylko jest gotowy do przyjmowania, wybierania dobrego i złego. Teraz wszystko zależy od tego, kto na tej czystej tablicy i jakim charakterem pisze ${ }^{3}$. Przede wszystkim Chrystus chce się na niej utrwalić. Niestety, tego chce także i szatan. Pomiędzy nimi toczy się walka o człowieka ${ }^{4}$. W człowieku jest coś ze światłości i ciemności, z tym, że stary człowiek grzechu z człowiekiem narodzonym z Chrystusa nie mogą na równi przebywać $\mathrm{w}$ jednej osobie. Zawsze jeden będzie panowal ${ }^{5}$.

Źródłem istnienia starego człowieka jest więc szatan, który sieje w człowieku zło. Ten stary człowiek - o którym mówi św. Paweł w słowach: „czuję w sobie inny zakon” - może być cielesny i duchowy, tzn. może objąć zmysłową, pożądliwą i gniewliwą część człowieka, oraz może

${ }^{2}$ Cwiczenia Narodzenia Pańskiego, Wes rkps 62, k. 21r. (cyt. dalej: Cwiczenia Narodzenia).

STamże, k. 25v.

${ }^{4}$ Tamże, k. $27 \mathrm{v}$.

5 Tamże, k. 26r; Praktyka abnegacji, Ossol. rkps 1264, k. 7v. (Cyt. dalej: Praktyka abnegacji). 
także zamieszkać w jego części duchowej, czyli we władzach duszy. W nich rozpoczyna się zło ${ }^{6}$. O. Stefan zaznacza, że władze zmysłowe i pożądliwe, a zowie je „częścią bestialską człowieka”, chociaż są przyczyną wielorakiego zła, nie są tak bardzo złe, ani nie mają w sobie takiej złości jak duchowy stary człowiek, tzn. wtedy, gdy zło przeniknie władze duchowe ${ }^{7}$. W nich bowiem mieszka on bardziej skrycie. Wtedy człowiek staje się jakby piekłem ${ }^{8}$.

Stary człowiek cielesny i duchowy mieszka w jednym człowieku, czyli w jego ciele i duszy w czworaki sposób. Opisanie sposobów zamieszkania prowadzi do bliższego sprecyzowania pojęcia starego człowieka. Tak więc stary człowiek,. ,syn gniewu”, mieszka w człowieku: a) przez przylgnięcie do grzechu ciężkiego, b) przez dobrowolne popełnienie grzechów wielkich powszednich, c) przez dobrowolne popełnienie małych grzechów lekkich, jakimi są nieostrożności, narażanie się na grzech, d) świadome wybieranie niedoskonałości, czyli mniejszego dobra, przez co człowiek hołduje minimalizmowi; tym samym szatan odwodzi człowieka od doskonałości ${ }^{9}$.

Przy tej okazji o. Stefan wchodzi w szczegóły, objaśniając na przykład w oparciu o władzę wzroku, jak stary człowiek zaczyna przenikać całego człowieka przez nieopanowanie patrzenia.

Pisze on, że w oczach jest wyniosłość pychy, w oczach jest łakomstwo pożądliwości, w oczach jest obżarstwo, w oczach jest lenistwo, itp. ${ }^{10}$ Stary człowiek bowiem wciąż kręci się koło siebie i objawia się w zmysłach. Tak Adam poszedł za oczyma swymi i stracił raj ${ }^{11}$. Stary człowiek, powiada dalej o. Stefan, jak Ezaw, który go wyobraża, prześladuje człowieka wewnętrznego, bogomyślnego, zawsze za czymś goni, ziemi się trzyma i w niej grzebie, namiętności zawsze są w nim żywe, ulega licznym nałogom ${ }^{12}$. W rzeczywistości Ezaw przeniósł miskę soczewicy nad dobro pierwszeństwa ${ }^{13}$.

W ten sposób o. Stefan odnajduje w ciele siedem grzechów głównych, które istnieją także w części duchowej, np. obżarstwo duchowe czy nieczystość duchowa ${ }^{14}$; idzie nawet dalej w swych twierdzeniach mówiąc, że wszelkie szukanie siebie, nawet $\mathrm{w}$ rzeczach dobrych, duchowych, czy cno-

6 Cwiczenia Narodzenia, jw., k. $24 \mathrm{r}$.

7 Tamże, k. 26r.

8 Tamże, k. 24 r.

9 Tamże, k. 22v.

10 Tamże, k. 23r.

11 jako mamy rodzić się z Niego, Wes rkps 62, k. 42. (Cyt. dalej: Jako mamy rodzić się).

12 Tamże, k. 43.

13 Praktyka abnegacji, jw., k. 13r.

14 Cwiczenia Narodzenia, jw., k. 21. 
tach, choć dalekie od grzechu śmiertelnego, trąci starym człowiekiem i nieprzyjemne jest Bogu oraz niebu ${ }^{15}$.

Stary więc człowiek to grzech i jego skutki w człowieku, to skłonność do grzechu, to nieuporządkowanie w zmysłach zewnętrznych i wewnętrznych, to złem przeniknięte władze duchowe. Stary człowiek to wszystko w człowieku, co nie jest pisane palcem Bożym i nie pochodzi od Boga, i nie prowadzi do Boga oraz do pełnego z Nim zjednoczenia ${ }^{16}$. Jeśli zatem człowiek pragnie dojść do tego przeobrażenia się w Boga, musi w sobie zniszczyć starego człowieka, inaczej mówiąc - porzucić i wzgardzić światem, wyniszczyć i krzyżować ciało wraz z namiętnościami ${ }^{17}$. Jeśliby tego nie uczynił, zapanuje w nim stary człowiek, a ten - choćby w postaci wybierania mniejszego zła - potrafi doprowadzić do upadku nawet świętego ${ }^{18}$. Dlatego człowiek musi podjąć pracę nad sobą ,,po cząstce znosząc i wyniszczając starego człowieka aż do całego wygnania", by Chrystus mógł się w nim narodzić ${ }^{19}$.

\section{Wyrzeczenie}

O. Stefan wiele mówi na temat wyrzeczenia, zastanawiając się nad samą jego istotą. Swoje rozważania popiera wieloma przykładami z Pisma św.

1. Pojęcie wyrzeczenia

Przede wszystkim człowiek, skoro ma podjąć pracę nad wyrzeczeniem, musi sobie uświadomić jego potrzebę. Zazwyczaj bowiem widzi siebie dobrym i uważa siebie za dobrego. Im dalej od Boga, tym więcej myśli o sobie i tym więcej w nim starego człowieka. O. Stefan, dążąc do uzasadnienia potrzeby wyrzeczenia, udowadnia człowiekowi, że nic nie znaczy jego dobroć. Tylko Bóg bowiem jest naprawdę dobry. Nawet Chrystus nie pozwalał nazywać się dobrym. Tym bardziej więc człowiek nie może zbyt wiele myśleć o sobie i o swej dobroci ${ }^{20}$. Miłość człowieka także jest mała; "raczej się jej sam wstydzić musi" ${ }^{21}$. Dodaje nadto, że niczym są wszystkie sprawiedliwości człowieka, jeśli Bóg nie zechce z tego ludz-

15 Tamże, k. 28r.

16 O gruncie pokory, Łobz rkps 0-20, s. 57-58 (cyt. dalej: O gruncie pokory); tamże: „Z tegoż biegu żywota ludzkiego rodzi się siedem wołów szpetnych... to jest straszne i niezwyczajne pokusy... siedem złości, wątpliwości... desperacji skrupułów... i drzazgi dla Boga podnieść nie może i słówka przykrego znieść... sam sobie jest zostawiony... w którym (stanie) nic nie waży, nic nie może”.

17 Tamże, s. 37.

18 Praktyka abnegacji, jw., k. 8r.

19 Cwiczenia Narodzenia, jw., k. 26r.

20 Oruncie pokory, jw., k. 37.

21 Tamże, s. 38. 
kiego nic ,góry zasług uczynić” ${ }^{22}$. Powołując się na przykład Joba powiada, że ten dopiero w utrapieniu poznał, iż sam z siebie nic nie ma i nic nie może ${ }^{23}$.

O. Stefan doskonale zdaje sobie sprawę kim jest człowiek i jakie są jego możliwości. Powiada np. o rozumie ludzkim, że ,jest szczerą pojętnością samego w sobie Boga”, wobec tego „ma pewien rodzaj nieskończoności... by mógł w sobie mieć tak wielkiego Boga" ${ }^{24}$. Mówiąc o nicości człowieka, o. Stefan chce tylko powiedzieć, że bez Boga człowiek nic nie znaczy i nic nie ma. Jeśli bowiem utraci Boga przez grzech, wraz z Nim utraci wszystkie dobra ${ }^{25}$. Właśnie to ,nic grzechowe” jest najgorsze w człowieku. Autor nie waha się je nazwać piekłem, które człowiek nosi w sobie, z tym, że jeszcze żyjąc na świecie, przez pokutę można znów stać się dzieckiem Bożym ${ }^{26}$, dojść do pierwotnej niewinności ${ }^{27}$. Odpowiadając na pytanie: ,przez co człowiek dochodzi do pierwszej niewinności?”, podkreśla — przez krzyż Chrystusowy. Przez krzyż rozumie: wzięcie krzyża, zaparcie samego siebie, umartwienie, stracenie duszy swojej, opuszczenie wszystkiego, oderwanie serca, wyniszczenie w duchu starego człowieka, ukrzyżowanie dla świata, ostrożność życia, czystość serca i sprzedanie wszystkiego ${ }^{28}$. Stwierdza przy tym, że jeśli człowiek wyrzeknie się wszystkiego, pozostanie mu prawdziwa „pojętność” Boga, którego może objąć w sposób naturalny, składając ,nieznanemu Bogu” wraz z ateńczykami hołd lub w sposób nadprzyrodzony żyjąc w pełni łaską chrztu Św. ${ }^{29}$

Wyrzeczenie, które człowiek powinien podjąć, może dotyczyć usunięcia przeszkód do zbawienia, a nimi są grzechy ciężkie; tych może uniknąc przez zachowanie przykazań. Może jednak człowiek iść dalej w wyrzeczeniu, podejmując miłość, ubóstwo i posłuszeństwo oraz odrzucając te rzeczy, których mógłby zażywać; wtedy staje się wolniejszy dla Bo$\mathrm{ga}^{30}$. Bo kto ustawicznie umiera sam $\mathrm{w}$ sobie, zawsze poczyna mieć $\mathrm{w}$ Bogu nowy żywot ${ }^{31}$.

\section{Istota wyrzeczenia}

Kilkakrotnie o. Stefan dotyka samej istoty wyrzeczenia. Czyni to, kiedy mówi o rezygnacji z wszystkiego, o czystości serca, czy też o samym

${ }^{22}$ Tamże, s. 39: „Za nic ich zbawiasz (Ps 32) aby możność i dobroć Jego uwielbiona była kiedy $\mathrm{z}$ piekła tego, którym jest grzesznik, tworzy niebo i z syna czartowskiego czyni anioła, Syna Bożego".

23 Tamże, s. 64.

24 Tamże, s. 36.

25 Tamże, s. 37.

${ }_{26}$ Tamże, s. $35-37$.

${ }^{27}$ Praktyka abnegacji, jw., k. 3v.

${ }_{28}$ Tamże, k. $3 \mathrm{v}$.

29 Tamże, k. 30 .

${ }^{30}$ Tamże, k. 33v.

31 Tamże, k. $34 \mathrm{v}$. 
wyrzeczeniu. Pisząc na temat rezygnacji powiada, że ona polega na tym, aby całkowicie zdać się na Boga, na Jego zdanie i wolę ${ }^{32}$. Ponieważ człowiek ma dojść do pełnej czystości serca i stać się przez to godnym przyjęcia daru Bożego, musi podjąć wyrzeczenie, które jest fundamentem tej czystości ${ }^{33}$. Wyrzeczenie więc ma doprowadzić do doskonałej czystości serca i przygotować na przyjęcie doskonałej miłości. Autor stwierdza przy tym, że wyrzeczenie jest wynalazkiem Mądrości Słowa Przedwiecznego. Chrystus Pan tak swoim przykładem jak i słowami uczy wyniszczenia starego człowieka wraz ze światem, z ciałem, ,synostwem czartowskim" i wszelkim grzechem, by w ten sposób doprowadzić do czystości, jaka była przed grzechem pierworodnym ${ }^{34}$.

Kiedy o. Stefan mówi o kontemplacji i miłości Bożej, zaznacza, że człowiek nie o nich ma myśleć, leç o całkowitym zaparciu się siebie. Dary zaś te, jeśli tylko zrobi na nie w sobie miejsce, same do niego przyjdą. Bóg sam chce je człowiekowi dać. One jakby same szukają człowieka. Jeśli przez wyrzeczenie odpowiednio się usposobi, ,same do niego wejdą i mieszkanie w nim uczynią" ${ }^{35}$. Ukazując człowieka umartwionego o. Stefan mówi: „Dusźa umartwiona podobna jest do grona dojrzałej słodyczy... bez rezygnacji jest grono cierpkie" ${ }^{36}$.

Przez podobieństwo rzeźbiarza, wykuwającego z kloca postać, chce wyjaśnić oczyszczające działanie wyrzeczenia i to się mu udaje. Takim bowiem klocem jest natura ludzka — ,jeden kloc żarem piekielnym i pożądliwościami zgrubiały". Chrystus bierze tę naturę ludzką, bo widzi, że „,w tym bałwanie jest śliczny posąg natury ludzkiej” i pomaga człowiekowi odrzucić wszystko, czego Bóg nie stworzył w nim, ,aż się pokaże człowiek jakiego Bóg sam w sobie stworzył" ${ }^{37}$. Ujęcie takie ukazuje co człowiek powinien odrzucić, mianowicie: „czego Bóg nie stworzył”, a więc: śmierć duszy i ciała, wszystkie grzechy tak wielkie jak i małe, nierząd, nieuporządkowane używanie świata, roztropność ciała i mądrość świata, niesprawiedliwość, niewstrzemięźliwość, niedyskrecję i zbytek. Jeśli człowiek to odrzuci, „zostanie się żywot ciała i duszy przez łaskę wzniecony" ${ }^{38}$. Potrzeba więc, by cały człowiek ,ppościł”, wyrzekał się

\footnotetext{
32 Tamże, k. 26.

33 Tamże, k. 2-3.

${ }^{34}$ Tamże, k. 1.

${ }_{35}$ Sposób ćwiczenia duchowego, Czerna AP rkps 27.3, k. 18. (Cyt. dalej: Sposób ćwiczenia duchowego).

${ }_{36}$ Praktyka abnegacji, jw., k. 35.

${ }_{37}$ Tamże, k. $2 \mathrm{v}$.

38 Sposób abnegacji, Ossol. rkps 1264 , k. 4v oraz k. 2r.: „Jeśli wyniszczy wszystko, czego Bóg nie stworzył... zostanie naczynie próżne, albo raczej jakaś przepaść bez dna szczerej pojętności Boga samego w sobie, która pojętność bogomyślnością staje się, miłością miłości staje się miłość... żeby Bóg stał się to wszystko przez łaskę, co Bóg ma przez naturę, mając w sobie pełność Boga, żelazo rozpalone pełne jest ognia przez wzajemne przenikanie, a obie substancje nie tracą".
} 
wszystkiego ze względu na Boga, jedynego pokarmu swej duszy. Wtedy „wejdzie z Mojżeszem na Synaj, z Eliaszem na Horeb, z Chrystusem na Tabor... i owszem, Chrystus sam wieczerzę z łaknącymi Boga uczyni z potraw bogomyślności i miłości" ${ }^{39}$.

Zbierając myśli o. Stefana na temat istoty wyrzeczenia, trzeba stwierdzić, że polega ono na rezygnacji ze starego człowieka, by stać się nowym, by napełnić się Bogiem samym i wszystkim w Bogu i tak powrócić do pierwotnej niewinności.

3. Przykłady wyrzeczenia

O. Stefan popiera potrzebę wyrzeczenia i jego istotę wieloma przykładami z Pisma św., z których nieliczne zostaną tu przytoczone.

Zachęcając do małych umartwień i wyrzeczeń pisze: „Popatrz się jako wiele szkody narobiła jedna mała soczewica i jabłko w raju... Stąd te maluczkie umartwienia masz sobie za wielkie" ${ }^{40}$.

Między innymi przypomina postać starca Eleazara jako wzór opanowania wszelkich najmniejszych słabości ${ }^{41}$.

Szeroko rozważa błogosławieństwo udzielone lewitom, błogosławieństwo, które jest wyłączeniem ich ze zwyczajnego używania doczesności i pisze: „Tacy mogą nieść kadzidło wonnej modlitwy na ofiarę Panu i samych siebie na całopalną ofiarę Bogu" ${ }^{42}$.

Autor wprowadza ciekawy wniosek ze zbierania manny w większej ilości wbrew zakazowi Pana, mianowicie: kto zbierał więcej lub w szabat, zbierał śmierć. To więcej bowiem się psuło i psuło człowieka. Trzeba więc umieć się wyrzekać. Praktyka wyrzeczenia ma nauczyć człowieka korzystania ze wszystkiego w sposób uporządkowany, tzn. „nie mniej i nie więcej i nie kiedy chcesz, ale jako niesie wola Boża" ${ }^{43}$.

Wspominając św. Jana Chrzciciela i jego życie pełne wyrzeczenia, pisze o opuszczeniu rodziców, zrezygnowaniu z małżeństwa, dzieci... bogactwa. Wylicza także opuszczenie żony (zrezygnowanie z małżeństwa) i dodaje: ,...i żony, która jest jak kamień młyński u szyji ponurzający w kłopotach i potrzebach świata" ${ }^{44}$.

Po wielu przykładach, autor stawia przed oczy wzór wyrzeczenia Jezusa Chrystusa, który w swej męce wyniszczył samego siebie i w boskiej i ludzkiej naturze. A wyniszczył się z honoru swego, z bogactw Boskich, nic sobie nie przypisując, ale Ojcu, aby przez to całkowite wyrzeczenie wać).

${ }^{39}$ Jako post odprawować, Wes rkps 62, k. 49v. (Cyt. dalej: Jako post odprawo-

40 Sposób abnegacji, jw., k. 14r.

41 Tamże, k. 17.

42 Tamże, k. $15 \mathrm{v}-16$.

${ }_{43}$ Tamże, k. $19 \mathrm{v}$.

${ }^{44}$ Exercita Adwentowe, rkps Wes 62, k. 14. (Cyt. dalej: Exercita Adwentowe). 
„Bóg był w nim wszystek" ${ }^{45}$. Wielokrotnie o. Stefan powraca do Męki Chrystusa jako wzoru wyrzeczenia i miłości przynaglającej. Stwierdza przy tym, że rozważane „cnoty wszystkie w męce Pana naszego" najpełniej przymuszają do wyniszczenia w nas: miłości własnej, wysokiego mniemania o sobie, woli własnej wraz z wolnością i zdaniem własnym ${ }^{46}$.

\section{Praktyka wyrzeczenia}

Przez wyrzeczenie ma się dokonać przemiana człowieka. Musi więc umrzeć stary człowiek, by mógł narodzić się nowy. Stary człowiek obejmuje całego człowieka - jego władze zmysłowe oraz jego władze duchowe. Oczyszczenie więc musi objąc tak zmysły i uczucia, jak i władze duszy. Gdy ono się dokona, będzie można mówić o prawdziwej czystości serca. W pewnym stopniu oczyszczenie dokonuje się całościowo. Wyrzeczenie bowiem podejmuje człowiek a on jest jednością. Niemniej praca nad oczyszczeniem musi się stopniowo rozwijać. Zacząć ją trzeba od podstaw. W dziełku "O gruncie pokory zwanej nic", a także w innej konferencji pt. "Jako mamy reformować i odrodzić $z$ Chrystusem ciało nasze $i$ zmysty" (na sześciu kartach), o. Stefan podaje prawie doskonały schemat całościowego wyrzeczenia ${ }^{47}$.

1. Reguły oczyszczenia

Zasadniczo o. Stefan podaje dwie reguły, z tym, że drugą rozbija na poszczególne drobne wyniszczenia. Warto je przytoczyć w całości.

a) „P i e r w s a r e g u ł a wyniszczenia się jest, aby kto we wszystkich uczynkach swoich i opuszczeniu samego Pana Boga szczerze szukał i miał w intencji, nie przymieszując samego siebie... tak, aby Pan Bóg był własną i całą przyczyną..., aby to co w sobie opuścił i zniszczył znalazł szczęśliwie w samym Bogu i ubóstwem swego nic Pana Boga w sobie odziedziczył" 48 .

Reguła podana przez o. Stefana domaga się całkowitego wyrzeczenia

45 O gruncie pokory, jw., s. 65 ; - O tym wyrzeczeniu się Chrystusa pisze na innym miejscu: „Wyrzekł się nawet Boskich przymiotów; z potencji, kiedy dał nad sobą wszystkim przewodzić, z męstwa i wielkości, kiedy się stał dziecięciem i dał ograniczyć malutkiemu ciału; z Państwa kiedy stał się poddany rodzicom i wszystkim władzom w Męce swojej. $\mathrm{Z}$ bogactw królewskich, kiedy stał się żebrakiem gołym. Z mądrości, kiedy się nie chciał, jakkoby nie umiał bronić na sądàch u Piłata, Heroda. Z dobroci, kiedy gromił władzę i między łotry był policzony. $\mathrm{Z}$ delicji, kiedy żywot swój starł prześladowaniem. Z nieśmiertelności, kiedy dał się zabić..." (Sposób abnegacji, jw., k. 20v).

46 Sposób abnegacji, jw., k. 29, oraz k. 28r.: „Uczy nas na modlitwie (w Ogrojcu) zaprzania własnej woli choć dobrej, ale naszej, żebyśmy za nasze wzięli wolę Bożą nieporównanie lepszą... Uczy nas przyjmować wszystko nie dla instrumentów Boskich, ale z rąk Ojca miłującego".

47 Jako mamy rodzić się, jw., s. 37-43.

$48 \mathrm{O}$ gruncie pokory, jw., s. 42. 
— „we wszystkich uczynkach”; wskazuje na cel jego - by „Bóg był własną i całą przyczyną" (postępowania), inaczej - by człowiek nie był poruszony przez miłość własną lecz przez samego Boga; jest to cel bliższy podjęcia wyrzeczenia, który można by nazwać za autorem intencją. Mówi także o celu ostatecznym, którym jest zjednoczenie z Bogiem. Wyrzeczenie jest właściwie oczyszczeniem, i nie pozbawieniem czegoś, lecz odzyskaniem tego w pełni w Bogu.

b) „Drugie r eguły wyniszczenia swego tak pojmuję, iż człowiek wiedząc, że przez siebie samego szczęśliwy nie jest ani być nie może, tylko przez co inszego... dobra honoru, bogactw i pociech te wyniszczyć (musi)" ${ }^{49}$. W tej regule autor podaje motywację wyniszczenia. Na nią składa się świadomość, że człowiek sam z siebie nie jest szczęśliwy, że nie mogą dać mu szczęścia dobra doczesne. Co więcej, one mu przeszkadzają w osiągnięciu tego dobra, które jedynie może go uszczęśliwić. Dlatego te przeszkadzające dobra trzeba w sobie wyniszczyć. Są to dobra honoru, bogactw i pociech. Autor mówi o wyniszczeniu, a chodzi mu o oczyszczenie, zreformowanie siebie i odrodzenie.

\section{Oczyszczenie spraw ciała}

Mówiąc o oczyszczeniu ciała, o. Stefan stawia naczelną zasadę: „Kto chce wziąc ducha, niech da ciało na krzyż" ${ }^{50}$. Wyjaśnia przy tym autor, że dusza nie potrzebuje zewnętrznego dobra. „Nic po majętności - pisze - nic po domu, ani po roli chleba z nich nie jada, pieniędzy nie potrzebuje" ${ }^{51}$. Człowiek więc powinien opuścić wszystko i to nie tylko zewnętrznie. Następnie autor przechodzi do szczegółowego omawiania tego „krzyżowania ciała”.

Proponuje ${ }^{52}$ więc a) oczyszczenie naturalnych dążeń człowieka, b) oczyszczenie zmysłów zewnętrznych, c) oczyszczenie zmysłów wewnętrznych, d) oczyszczenie uczuć (pasji). Przy tej okazji podaje wiele ciekawych myśli. Przede wszystkim zaś stwierdza, że ze swymi władzami trzeba się liczyć, brać je pod uwagę w pracy nad sobą oraz widzieć w nich dobro dane od Pana. Wszystkie je można wykorzystać do wzrostu w miłości Bożej. e) Oczyszczenie „świata racji doczesnej”. - O. Stefan główny nacisk kładzie na oczyszczenie honoru ciała, bogactwa ciała i pociechy ciała".

- Człowiek bardzo zabiega o swe wywyższenie. Tak bardzo ceni sobie z jakiej rodziny pochodzi, jakie ona ma bogactwa, ile i jakie ma stroje, itp. Rzeczywiście w ludzkim pojęciu taki człowiek zasługuje na cześć

\footnotetext{
49 Tamże, s. 42.

50 Baranek Wielkanocny, rkps Wes 65, k. 87. (Cyt. dalej Baranek Wielkanocny). 51 Tamże, k. 95.

52 Ujęcia a), b), c) i d) podaję w streszczeniu.
} 
i szacunek. O. Stefan rozważając to mówi: „wszystko to trzeba umartwieniem w nic obrócić, które to nic im głębsze budujemy, tym Pana Boga bardziej i wyżej wystawiamy" ${ }^{53}$.

- Człowiekowi zależy na bogactwie. Człowiek zabiega o majątek, gromadzi złoto, srebro, buduje pałace, ogrody... To wszystko potrzebne jest ciału. Dusza tego nie potrzebuje, „żyje bowiem bez tych rzeczy, którymi żyje ciało". Dlatego Chrystus radzi opuścić bogactwa ${ }^{54}$.

- Człowiek troszczy się o pociechy ciała, tzn. przyjemności płynące ze zmysłów i ich zaspokojenia. Człowiek odczuwa zadowolenie ze swego pochodzenia, pokrewieństwa. Człowiek zatrzymuje się na radościach, których mu dostarcza wyobraźnia ${ }^{55}$. Obok zaś niego przechodzi prawdziwe życie.

Potrzeba więc zaparcia się honoru, wyrzeczenia ducha świata i ciała, zbiorów, dostatków i wygód, pociech i rekreacji; trzeba ograniczyć podejmowanie prac, które są ze szkodą dla ducha: wyrzec się radości z zzewnętrznej działalności nawet tak świętej jak budowanie kościołów, kalwarii, jeśli przez to równocześnie zaniedbuje się rozwój życia ẇewnętrznego ${ }^{56}$.

\section{Oczyszczenie rozumu i pamięci}

Podobnie jak przy oczyszczeniu ciała, mówi o. Stefan o wyniszczeniu „honoru rozumu, bogactwa rozumu, pociech rozumu".

- Przez „honor rozumu” pojmuje wywyższanie się nad drugich. Człowiek uważa siebie, że jeśt lepszy od nich, mądrzejszy, bardziej biegły; zalicza tu także ubieganie się o ludzką opinię. Człowiek, który dąży do wywyższenia i uczczenia Boga w sobie, będzie się starał umartwić wszelki honor w sobie. Według powiedzenia o. Stefana „nasz honor wszystek ma umrzeć" ${ }^{57}$.

- Nie jest dobrze, kiedy człowiek wykorzystuje „,bogactwo swego rozumu" dla zdobycia i posiadania wielu rzeczy np.: jeśli zdobywa wiedzę - doktorat z filozofii czy teologii, jak to zaznacza o. Stefan, by wraz z tym osiągnąc byt syty. Trzeba więc oczyścić rozum wraz z jego bogactwami, aby sam Bóg mógł wejść do człowieka i stać się jego bogactwem ${ }^{58}$.

$\$^{3}$ O gruncie pokory, jw., s. 42 .

54 Tamże, s. $44-45$ oraz s. $71-72$ : „Ludzie - zauważa przy tym - szanują tylko bogatych, ubogimi gardzą, a takich jest królestwo niebieskie”. Autor jeszcze dodaje: „Owszem i Boga samego sobie przywłaszczają” (Tamże). A oto wyliczone dobra, których każe się wyrzekać: bogactwa powierzchowne, bogactwa ciała, bogactwa duszy (niższej części), bogactwa szczerego ducha, np. dobroć, wielkość, bogactwo wierzcholka ducha, np. dobroć, bogomyślność..." W zażywaniu ty.ch dóbr nie ma sobie czlowiek mic przywłaszczać, aby był ubogi przed Bogiem"; Baranek Wielkanocny, jw., k. 95; Lampa Wes rkps 62, s. 69. (Cyt. dalej: Lampa).

55 O gruncie pokory, jw., s. 47-48.

56 Bez tytułu, Czerna AP rkps 246, s. $345-348$.

57 O gruncie pokory, jw., s. $42-43$.

58 Tamże, s. 45-46; Jako mamy rodzić się, jw., k. 41 
Bogactwo rozumu czyli jego przymioty mogą prowadzić do upodobania w sobie, mogą rodzić zadowolenie i pociechę z siebie. Wiedża, jeśli nie jest oparta na miłości Bożej i pokorze, nadyma. Można się kochać i rozkoszować w swej wiedzy jak szatan w swoim dowcipie, w swoich - powiada o. Stefan - koncepcjach ,primae et secundae classis”; czy też „drukowaniem kazań chcąc się zalecać ludziom”. Człowiek może znać wszystkie stopnie modlitwy, pokory, a samemu nie postąpić i innych przez subtelne rozważania sprowadzić z drogi doskonałości ${ }^{59}$.

Dlatego, by ustrzec się pychy rozumu, trzeba rozum nasycić tylko prawdą, którą jest Chrystus - „Jam jest prawda" ${ }^{60}$ : I tu dobrze będzie przytoczyć wskazania o. Stefana dotyczące wyrzeczenia rozumu. Mianowicie zaleca, aby spojrzeć na rzeczy doczesne przez Objawienie; na godność i sławę jak Chrystus na nie patrzył, mając „rozsądek własny i wolę

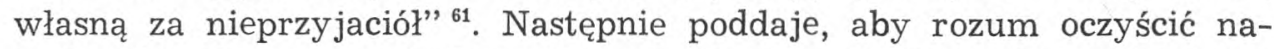
wet z obrazów czysto duchowych, np. odnośnie do Boga nie wyobrażając Go sobie, bo „Pan Bóg nic nie jest z tego cokolwiek rozum ludzki o Nim sobie przez siły (natury) fabrykuje" ${ }^{62}$. W tym oczyszczeniu dopomaga posłuszeństwo. Właśnie ono oczyszcza człowieka „,z rozsądku własnego i dyskursów jego" ${ }^{63}$.

Tak oczyszczony rozum napełnia się Bogiem i w Bogu Jego łaską „odnajduje jakby raj umysłowy z zażywaniem Boga" ${ }^{64}$.

Równocześnie z rozumem i pamięć potrzebuje oczyszczenia. Jest ona oparta na tym, co zmysły doznają i co przez nie dociera do umysłu. Jeśli człowiek napełni ją rzeczami doczesnymi, nie będzie w niej miejsca dla Boga ${ }^{65}$.

4. Oczyszczenie ducha

O. Stefan rozróżnia władze duchowe od najważniejszych części ducha i twierdzi, że obok oczyszczenia rozumu, pamịcei i woli, trzeba także oczyścić samego ducha. Już samo oczyszczenie władz stwarza wiele trudu.

59 O gruncie pokory, jw., s. 49: ,Zna on (szatan) wszystkie stopnie miłości Bożej, pokory - pisze tamże o. Stefan - ale przez nie nie wstępuje... W czym go zwykli naśladować uczeni oziębli, którzy szerokością nauk, godzi się może, nie masz tu nic ani grzechu powszedniego, ściągają wielu z drabiny doskonałości".

60 Baranek Wielkanocny, jw., k. 97.

61 Tamże, k. 100.

62 Dwanaście stopniów zachowania przykazania Bożego, Czerna rkps 246, s. 320. (Cyt. dalej: Dwanaście stopniów).

${ }_{63}$ O gruncie pokory, jw., s. 75; Baranek Wielkanocny, jw., k. 124.

${ }_{64}$ Jako post odprawować, jw., k. 49, także: O gruncie pokory, jw., s. $32 \mathrm{v}$ : „W tej części wyczyszczony cale wraca się nam raj umysłowy - pisze autor - z zażywaniem Boga i Chrystusa, który jest drzewem żywota".

${ }^{65}$ Jako mamy post odprawować, jw., k. 49: „Pamięć teź bestialska - pisze ma być dla postu chudą spiżarnią, bo gdzie ją człowiek zatka bardzo i obetka rzeczami doczesnymi, tam człowieczeństwo Chrystusa i Męka Jego miejsca mieć nie może". 
Trzeba je jednak oczyścić, gdyż rzeczy doczesne je zacieśniają ${ }^{66}$. Tym więcej trzeba wysiłku, by duch mógł zapanować nad materią, by ducha przysposobić do przyjęcia Boga i całkowicie poddać go woli Bożej ${ }^{67}$.

Oczyszczenie ducha omawia o. Stefan w sposób podobny jak to czynił już uprzednio. Domaga się więc wyniszczenia: „honoru dobra doczesnego, bogactwa duchowego i pociech duchowych".

- Człowiek bowiem często chlubi się z duchowych wartości: ze stanu duchowego, z prowadzenia życia duchowego, z życia cnotliwego, z podejmowanego wysiłku w pracy nad sobą, szczególnie dlatego, by $\mathrm{u}$ innych mieć uznanie itp. O. Stefan daje radę, by „,człowiek nie starał się o cnoty ani dary boskie dla swojej wielkości, estymacji u ludzi" "68. Wyjaśnia nadto, że cnotę można i należy używać, a nie zażywać — ,samego Boga tylko można zażywać" ${ }^{69}$.

- Człowiek otrzymuje od Boga dary, zdobywa bogactwa duchowe. Są nimi: miłość Boża, dary Ducha Świętego, bogomyślność... Nie powinien jednak ich sobie przywłaszczać, przypisywać sobie samemu. Sam bowiem z siebie jest ubogi. Jeśli sobie przypisze dary Boże, uwłacza Bogu i nie oddaje $\mathrm{Mu}$ co do Niego należy. A przecież tylko dzięki łasce Bożej człowiek jest bogomyślny i cnotliwy. Dodaje przy tym: „Nie chciej być bogaty dobrami duchowymi w sobie, ale samemu Bogu... które (to dary) tobie się w posesję daje" "70.

- Człowiek szuka pociech. Pewne wartości przeżywane wywołują u niego radość. W tym może brać udział także ciało, jak to mówi Psalmista: „Serce moje i ciało rozradowało się w Bogu żywym” (Ps 83). Istnieją pociechy nie oparte na miłości. Takimi są wtedy, gdy człowiek ma upodobanie w dobru, w cnocie, lecz ich nie spełnia. Są także pociechy czysto duchowe według słów Maryi: „I rozradował się duch mój w Bogu, Zbawicielu moim". Takie pociechy są zazwyczaj z najwyższej części ducha ${ }^{71}$. Pociechy te dotyczą wszelkich cnót, stopni kontemplacji... I tych trzeba się wyrzekać, ,ile w nich jest cokolwiek naszego własnego i zażywania pociech naszych z szukaniem naszym". Wyjaśnia przy tym, że aniołowie posiadali te wszystkie dobra, lecz ponieważ szukali pociech w sobie, stracili wszystko ${ }^{72}$.

Tak ustawione wyrzeczenie się pociech nie oznacza zaniedbania dobrych uczynków i cnót. Chodzi jedynie o to, aby w nich nie szukać sie-

${ }^{66}$ Baranek Wielkanocny, jw., k. 99.

67 Tamże, k. 101.

68 O gruncie pokory, jw., s. 43.

69 Tamże, s. 74-75: „Najlepsza tedy rzecz jest i od dobrych duchowych pociech umykać się i na miejsce ich raczej wziąć krzyż gorzkości i cnót samych z pociechą nie zażywać".

70 Tamże, s. 46.

${ }_{71}$ Tamże, S. 50-51.

72 Tamże, s. 52. 
bie. One same w sobie mogą być dobre, a nawet stać się nawiedzeniem Bożym. Szukanie ich jednak oraz pragnienie oznacza, że jeszcze Bóg nie stał się wszystkim dla człowieka. O. Stefan tak ujmuje tę sprawę: (ponieważ) „wierzy Bogu i duszy swojej, wyrzeka się wszystkich faworów, wizji, raptów, rewelacji" ${ }^{73} \ldots$

5. Oczyszczenie woli

W swych rozważaniach autor idzie jeszcze dalej stwierdzając, że na tej drodze nie tyle chodzi o umiejętności, co o upokorzenia i zaparcia własnej woli ${ }^{74}$, by przez umartwienie woli i własnego zdania zdobyć czystość doskonałą serca i tak oczyszczoną duszę poddać Bogu w darze całopalnym ${ }^{75}$.

Odnośnie do woli własnej stwierdza, że ona może niszczyć dobre uczynki, Komunie św., umartwienia, modlitwy, posty... Z woli własnej czyli dla swego jedynie upodobania można wszystko opuścić, wstąpić do zakonu. W tym bowiem wszystkim można szukać jedynie siebie i swoich spraw, przywłaszczając sobie dary Boże ${ }^{76}$. Dlatego o. Stefan podaje pewne reguły oczyszczenia woli własnej, mianowicie:

— by wola nasza i zdanie poczynały się z Boga, woli Bożej — „rodziły się z Boga jak światłość ze światłości lub obraz z obrazu";

- by wola nasza i sąd o rzeczach były odbiciem woli i sądu Bożego ,żeby w naszej woli i zdaniu wola Boża i sąd mieszkały, przez nie chciały" ${ }^{7 ?}$.

Ten stan można osiągnąć, poddając się pod kierownictwo we wszystkich sprawach oraz przez rozważanie z jakiej przyczyny pochodzi i do jakiego końca zmierza wszystko, cokolwiek czynimy, opuszczamy, mówimy lub myślimy ${ }^{78}$.

6. Wyrzeczenie się wszystkiego

Wszystkie wyżej wymienione wyrzeczenia zbiera o. Stefan w jedną całość, omawiając stopnie ubóstwa oraz swoje „nic”. I tak zaleca:

- ubóstwo w posiadaniu: żeby nic własnego i na własność nie mieć, otrzymanego zaś dobra jedynie wtedy, gdy jest potrzeba używać; nie mieć troski o gromadzenie dobra;

- ubóstwa ciała: uwolnić się od wszelkich pożądliwości cielesnych,

73 Tamże, s. 74.

74 Exercita Adwentowe, jw., k. 11.

75 Lampa, jw., k. 69; Jako post odprawować, jw., k. 48.

76 Co to jest wola wtasna, Czerna AP rkps 246, s. 303-305; pisze tam: „Pan Bóg nie jest początkiem jego uczynku".

77 Tamże, s. 305 .

78 Tamże, s. 306; „Nechaj każdy - pił̧ze - stara się na miejsce woli własnej położyć wolę Bożą i oną chcieć albo nie chcieć, a wola własna ma się mieć naczyniem, instrumentem".

30 - Analecta Cracoviensia 
zdobyć wolność od wszystkich wygód i pieszczot ciała, wolność od wszelkiej ziemskiej miłości;

- ubóstwo duszy: pamięć ma być wolna od rzeczy stworzonych, rozum oczyszczony od figur i podobieństw stworzonych, wola nie może mieć upodobania ani w rzeczach stworzonych, ani w cnotach i darach boskich, lecz zdana na Boga i Jego upodobanie ${ }^{79}$.

Pozostaje więc wyniszczyć w sobie całe swoje bogactwo, by mieć w sobie tylko „nic" - tzn. człowiek powinien dojść do świadomości, że „nic nie jest, nic nie ma, nic nie umie, nic nie może", poznając przepaść swojej nicości ${ }^{80}$. Jednym słowem człowiek, musi uznać, że nic nie ma z siebie, a wszystko ma z Boga ${ }^{81}$. Ta przepaść naszego nic przyzywa przepaść wszystkiego dobra, aż do wypełnienia nim ${ }^{82}$.

Jednym słowem trzeba sprzedać wszystko, sprzedać zaś wszystko, to zamienić ziemię na niebo, ciało na ducha, siebie samego na Boga, czas na wieczność ${ }^{83}$, aż człowiek przez usunięcie wszystkiego stanie się obrazem Boga ${ }^{84}$.

\section{Sposoby wyrzeczenia}

Wyrzeczenie - jak podaje o. Stefan - dokonuje się przez cnoty teologiczne, rady ewangeliczne, dary Ducha Swiętego i przez przyoblekanie się w Chrystusa.

- W szczególny sposób oczyszczenie dokonuje się przez c n o t y t e olo g i c z n e. Im głębsza wiara tym mocniej oczyszcza. Rozum oczyszczony w wierze wszystko widzi w prawdzie. Nadzieja skierowuje ku Bogu, wyniszczając istniejące w człowieku rozdwojenie. Człowiek umocniony w nadziei nawet nie myśli o dniu następnym, czy też o tym, że mu się coś od Boga należy. Miłość ku Bogu w miarę swego wzrostu „,w nic obraca miłość własną" i czyni człowieka niewolnikiem Jego miłości ${ }^{85}$.

- W tym oczyszczeniu pomagają $r$ ady e wangeliczne. Przez nie bowiem człowiek siebie składa w darze Bogu. Rada ubóstwa jest złożeniem Bogu całego dobra ziemskiego. Przez radę czystości człowiek oddaje Bogu ,ciało i krew z pociechami swymi”. Wraz z radą posłuszeństwa

${ }^{79} \mathrm{O}$ gruncie pokory, jw., s. 72-73.

80 Tamże, s. 70.

81 Tamże, s. 35: „Szczęśliwy, który umie tak dzielić w przepaści swojej, co w nim jest dziełem łaski Bożej, od tego co się w nim własnego zostaje".

${ }_{82}$ Tamże, s. 76; Autor powołuje się na "Noc ciemna" św. Jana od Krzyża. r. III, wyjaśniając: „Gdzie masz szósty sposób praktyczny obracania się w nic głębokiej pokory, przez którą człowiek tym bardziej Boga wynosi, im bardziej siebie poniża i w nic obraca i Bogu miejsce opróżnione czyni, aby Bóg w jego naczyniu umysłowym zamieszkał" (tamże, s. 41).

${ }^{83}$ Praktyka abnegacji, jw., k. 26v.

84 Tamże, k. 4r.

85 O gruncie pokory, jw., s. 75 . 
składa B̉ogu własną duszę i wolność... Już więcej nic nadto dać nie może ${ }^{86}$.

- Jeszcze większego oczyszczenia dokonują da r y D u cha S wi ęt e g o, sprowadzając Jego owoce ${ }^{87}$. O. Stefan dary te nazywa subtelnymi narzędziami zdolnymi oczyścić z najmniejszych przewinień i słabości ${ }^{88}$.

- W dokonywaniu tego całościowego oczyszczenia wzorem jest Chrystus ${ }^{89}$. O. Ignacy od św Jana Ewangelisty, autor życiorysu c. Stefana, omawiając jego praktykę umartwienia opisuje, jak ten w oparciu o przeżywanie Męki Pańskiej oczyszczał siebie całego. Przytacza również jakby akty strzeliste o. Stefana - nie umieszczone w żadnym znanym jego piśmie - a dotyczące oczyszczenia poszczególnych władz. Oto akt odnośny oczyszczenia pamięci zmysłowej: ,przez miłość Jezusa mego wyrzucam wszelkie pamiętanie o pociechach... rzeczach stwözonych... tylko tak, jeśliby mi pamiątka tych rzeczy służyła do naśladowania Chrystusa Pana w cnotach... Inaczej wszystko precz oddalam... Ale chce pamiętać na Człowieczeństwo Chrystusowe i Jego obecność, na tajemnicę żywota i Męki Zbawiiciela naszego - wszechrzeczy by najmniejszej w pamięci z Nim nie trzymać" ${ }^{\mathbf{0}}$.

Dobrze będzie te rozważania o. Stefana na temat wyrzeczenia zakończyć jego własnymi słowami, w których kreśli korzyści, jakie przynosi wyrz€czenie: ,Zaprzyj się wszystkich bogactw łakomstwa, zostanie się w tobie ubóstwo w duchu i Królestwo niebieskie... Odejmij pociechy cielesne, zostanie w tobie zażywanie chleba rajskiego bogomyślności prawdy i napoju, które wszelkie pragnienie całe gasi... Wyrzec się samego siebie we wszystkim, znajdziesz samego Boga we wszystkich rzeczach. Opuść wszystek świat stary, znajdziesz nowy raj w Bogu i mieszkanie w Nim. Odetnij wszystkie nieporządne zażywanie rzeczy doczesnych, znajdziesz w sobie zażywanie boskich z Bogiem. Wyniszcz w sobie obraz czartowski, znajdziesz w sobie stworzony obraz Boży i szczęście wieczne" "1.

${ }^{86}$ Praktyka ćwiczenia $w$ abnegacji, Ossol. rkps 1264, k. 34r.; Baranek Wielkanocny, jw., k. 126.

87 Baranek Wielkanocny, jw., k. 129.

${ }_{88}$ Praktyka abnegacji, jw., k. 6r.

${ }^{89}$,Ubóstwo także Chrystusowe wyzuwa i wyniszcza nas z wszystkiego aż do nie mienia tylko naszego nic, które jest pełne niezmiernego ubóstwa nagiego. Przyczyna i potrzeba tak wielkiego zubożenia naszego i w nic obrócenia nie inna jeno ta, że Pan Bóg żadną miarą nie chce się zgodzić w sercu ludzkim z rzeczami stworzonymi... bo sam chce serce ludzkie opanować, posiąść i sam napelnić sobą i dać się w dziedzictwo człowiekowi. Przez ubóstwo chce go ze wszystkiego wyzuć i wyniszczyć, aby samym Bogiem człowiek był bogaty" - $O$ gruncie pokory, jw., $\mathrm{s}$. $69-70$.

${ }_{90}$ Wizerunek, Wes rkps 22, k. 48.

${ }^{91}$ Praktyka abnegacji, jw., k. 5r. 
Oczyszczenie starego człowieka jest tylko jedną stroną - negatywną - pracy nad sobą i nad realizowaniem swego powołania. Drugą stroną, pozytywną i zasadniczą, jest według o. Stefana przyobleczenie się w nowego człowieka. Autor wszystko, cokolwiek mówi czy pisze, ujmuje pod kątem tego nowego człowieka. Dlatego po omówieniu wyrzeczenia, należy przedstawić naukę o. Stefana o nowym człowieku i przyoblekaniu się w niego. W tym celu zostanie ukazany obraz nowego człowieka, następnie zostaną przedstawione cnoty, jakimi on powinien się odznaczać, oraz zostanie podany sposób tego przyoblekania się - naśladowanie Jezusa Chrystusa.

\section{Obraz nowego człowieka}

Kiedy mówi się o nowym człowieku, staje przed oczyma pierwszy człowiek chodzący w nowości otrzymanego życia, jego upadek, przez który stary człowiek zamieszkał w człowieku, oraz Nowy Człowiek Jezus Chrystus. W taki sposób ustawia te zagadnienia o. Stefan ${ }^{92}$.

1. Koncepcja nowego człowieka

O. Stefan stwierdza, że u pierwszego człowieka był raj, tzn. Bóg mieszkał w jego istocie, dzięki czemu wszystko w człowieku było uporządkowane. Skoro człowiek jednak poszedł - mówi obrazowo - za swymi oczami, utracił ten wewnętrzny raj ${ }^{93}$. Dla odzyskania tego „utraconego raju" czyli uporządkowania siebie trzeba zwycięstwa nad sobą samym, czyli czystości ciała, czystości duszy i czystości ducha ${ }^{94}$. Takie jest też pierwsze, a zarazem ramowe określenie nowego człowieka. Krótko można by je ująć tak: nowy człowiek, to człowiek czystego serca.

Autor nie poprzestaje na ogólnym tylko określeniu nowego człowieka, lecz wchodzi w szczegóły. W tym ujęciu nowy człowiek, to człowiel. ześrodkowany w Bogu; człowiek, który usiłuje przebywać w raju - w stanie uporządkowania; człowiek, który usuwa przeszkody; człowiek, który nieustannie powraca do swego wnętrza i w. Bogu odnajduje nowy świat ${ }^{95}$. Jednym słowem - autor w oparciu o porównanie Jakuba z Ezawem powiada - nowy człowiek mieszka w domu i jest bogomyślny.

Nie bez szczególnej racji o. Stefan przypomina pierwszego człowieka i jego trwanie w raju. Przez takie ujęcie pragnie podkreślić, że człowiek w swej istocie jest zdolny do stania się nowym człowiekiem, czyli zdol-

92 Baranek Wielkanocny, jw., k. 110r.

93 Jako mamy się rodzić, jw., k. 42.

94 Praktyka abnegacji, jw., k. 26r.

95 Jako mamy się roфzić, jw., k. 43. 
ny do przyjęcia pełnego szczęścia od Boga w Trójcy Jedynego. Wtedy w człowieku wszystko jest poddane Bogu, wszystko prowadzi go do Boga, we wszystkim widzi Boga ${ }^{96}$. O. Stefan pisze, że człowiek jest królową Sabą, tzn. rozumem i wolą wpatrzony w Boga. Człowiek jest miastem i królestwem Boga; jemu dano poznać tajemnice królestwa Bożego; wszystko w nim jest ułożone; jest człowiekiem sprawiedliwym; od Boga przyjmuje wszystko dobro i doświadczenia ${ }^{97}$.

Mówiąc o tym ,jak mamy z Chrystusem wstępować do nieba”, autor dorzuca jeszcze następne szczegóły nowego człowieka. Staje się on nowym człowiekiem, kiedy duszą i ciałem odrywa się od ziemi, kiedy żyje duchem, kiedy bardziej ochotny jest do cnoty niż przedtem był do grzechu, kiedy Boga Ojca nie szuka już.w jakimś miejscu, czy na niebie, lecz odnajduje Go i zażywa w sobie ${ }^{98}$.

Bóg w ten sposób w człowieku obecny i przeżywany jest źródłem wszystkiego dobra. Dzięki darowi, jaki Bóg składa człowiekowi z samego siebie, rozpoczyna się rodzić nowy człowiek, a łaska Boża zaczyna przenikać całą jego istotę, działając w nim przez trzy cnoty Boskie ${ }^{99}$. Aby Bóg obecny w człowieku mógł działać, istnieje konieczność odrodzenia się; potrzebna bardzo wielka czystość duszy i ciała: „Wtedy (człowiek) jest jak tablica goła albo płótna wygruntowane na przyjęcie obrazu... staje się jedno... nic z sübstancji swojej nie tracąc" ${ }^{100}$. Wyjaśniając tę jedność pisze o. Stefan, że można stać się jedno z Bogiem, z niebem, ale i z ziemią, z piekłem i szatanem, w zależności od tego, czym człowiek się napełnia ${ }^{101}$. Zarazem jednak podkreśla, mówiąc o staniu się dzieckiem, że ,,jeśli (człowiek) stanie się nim, staje się pojętnością albo przepaścią dziwnej pojętności", którą może wypełnić tylko sam Bóg ${ }^{102}$.

2. Bóg obecny w nowym człowieku

Fundamentem nowego życia w człowieku jest zatem Bóg w nim obecny. Pragnąc głębiej objaśnić możliwość i sposób obecności Boga w człowieku, o. Stefan zaznacza, że w nim mieszka Bóg w Trójcy Jedyny i Chrystus w swoim człowieczeństwie ${ }^{103}$.

${ }_{96}$ Saba, Wes rkps $62, \mathrm{k}, 75 \mathrm{v}$. „Dusza jest jak tablica goła... jest szczera jakaś pojętność i sposobność do przyjęcia wszystkiego szczęścia Boga w Trójcy Jedynego".

97 Tamże, k. 76.

98 Jako mamy wniebowstępować, Wes rkps 62, k. 62. (Cyt. dalej: Jako mamy wniebowstępować).

99 Cwiczenia Narodzenia, jw., k. 33.

100 Tamże, k. 35.

101 Tamże, k. 35.

102 Tamże, k. 35.

103 O trojakiej gubernacji serca, Czerna AP rkps 246, s. 287; (cyt. dalej: O trojakiej gubernacji); Jeruzalem, Wes rkps 62, k. 45 (cyt. dalej: Jeruzalem); O wzięciu Ducha Swiętego, Czerna AP rkps 246, s. 262 (cyt. dalej: O wzięciu Ducha). 
Niemniej na swój sposób mieszkają także aniołowie, mieszkają ludzie, np. kiedy człowiek pragnie pozyskać miłość, pragnie być z umiłowanym, i będąc kochanym jest $w$ umiłowanym ${ }^{104}$.

Rozwijając tę myśl, pisze: „W ten sposób wielgie zgromadzenie inszych ludzi w jednym człowieku mieszkają" ${ }^{105}$. Pragnie w ten sposób uzasadnić możliwość zamieszkania także Boga w człowieku. Bóg bowiem mieszka w nim w podobny sposób.

Opisując samo zamieszkanie Boga w człowieku powiada, że Bóg mieszka w nim przez swoją istotę, przez swoją obecność, przez swoją potęgę. Są to podstawowe sposoby obecności Boga w człowieku. W ten sposób Bóg może przebywać tak w dobrych, jak i złych. W nowym człowieku Bóg jest obecny przez laskę, przez obcowanie, przez widzenie i jasną znajomość, przez miłość, która Boga kosztuje. Bóg wtedy przebywa w człowieku jak poznawany w poznającym i jak rzecz umiłowana w miłującym ${ }^{106}$. Wyrraźnie rozróżnia o. Stefan obecność Boga w człowieku przez łaskę i przez miłość, podkreślając zarazem, że Bóg stara się przebywać w umiłowanym, w „miłości ludzkiej” — przez pozyskanie człowieka. Chce pozyskać sobie jego miłość do tego stopnia, „że się da dla niego zabić” ${ }^{107}$. Tę obecność Boga przez miłość nazywa autor „,posesją rozumu i woli". W jego ujęciu takie przenikanie wzajemne jest ściślejsze niż może to sprawić bliskość fizyczna, gdyż jest to bliskość duchowa ${ }^{108}$.

Obecność Boża świadomie przeżywana jednoczy wszystkie siły - dotąd rozproszone po innych władzach - w jedno i ześrodkowuje je na samym Bogu. Bóg obecny w człowieku bierze w posiadanie ,wierzchołek ducha" i teraz do niego ciąży całe życie wewnętrzne człowieka. To zespolenie z Bogiem obecnym angażuje również zmysły i ciało ${ }^{109}$.

Człowiek staje się szczęśliwy w tej obecności. Boga. Ona bowiem sprawia, że jest w sobie uporządkowany wobec Boga, wobec siebie samego i wobec bliźnich, posiadając w sobie cztery cnoty kardynalne wraz z pochodnymi od nich cnotami moralnymi ${ }^{110}$.

Rozważając tę obecność Bożą w człowieku, autor zapytuje w której części człowieka mieszka nowy człowiek? O. Stefan odpowiada, że nowy człowiek mieszka w zmysłach zewnętrznych i wewnętrznych, w uczu-

104 O trojakiej gubernacji, jw., s. 292.

105 Tamże, s. 291.

${ }^{106}$ Tamże, s. 287-292; Tak o tym pisze na innym miejscu: „W tym tedy mieście lubo w człowieku nowym mieszka sam Pan Bóg nie tylko przez istność i potencję ale też przez łaskę swoją, przez przyjaźń, przez konwersację, przez widzenie i znajomość jasną, przez miłość zażywającą, przez chwałę wielką i uchylenie jej majestatu swego; mieszka przez estymację wielką sicut amatum in amante et cognitum in cognoscente" - Jeruzalem, jw., k. 45.

107 O trojakiej gubernacji, jw., s. 292.

108 Tamże, s. 293-294.

109 Jako mamy rodzić się, jw., k. 43.

110 O trojakiej gubernacji, jw., s. 297. 
ciach i władzach duchowych ${ }^{111}$, czyli tak samo jak mieszka stary człowiek. Obecnie te same władze po oczyszczeniu ich i zamieszkaniu w nich Boga - wszystkie razem - nazywają się nowym człowiekiem. Ta rzeczywistość oznacza, że wszystkie władze same w sobie są dobre. Człowiek jedynie może je skierować ku złemu. W dalszym ciągu autor wyjaśnia, porównując człowieka do pałacu czy domu Bożego, w jaki sposób nowy człowiek w nim mieszka, np.: ,w sile rodzącej mieszka przez cnotę czystości, w sile karmiącej przez wstrzemięźliwość i post" itd. ${ }^{112}$ Władze duszy także są zjednoczone z Bogiem, który mieszka w rozumie przez rozważanie człowieczeństwa Chrystusowego, przez kontemplację nieskończonej dobroci Boga, przez spojrzenie wiarą na wszystko i na Boga samego; który mieszka w woli przez miłość zrodzoną z wiary, uczucie płynące z kontemplacji, przez radosne przyswojenie sobie wszystkich cnót Chrystusowych ${ }^{113}$. Ponieważ wszystko zostało uporządkowane według rad Chrystusowych, Bóg mieszka jakby w każdym włóknie istoty ludzkiej ${ }^{114}$, a człowiek całą swą istotą chwali Boga, albo raczej sam Pan Bóg chwali samego siebie w człowieku ${ }^{115}$.

Dzieła obecności Boga i zjednoczenia z Nim w miłości dopełnia Duch Święty, który nieustannie udzielany, działa w zależności od stopnia życia duchowego. Na drodze oczyszczającej jest On odpuszczeniem grzechów, na drodze oświecającej jest poznaniem wszelkiej prawdy, na drodze zaś jednoczącej uroczyście wstępuje w człowieka, staje się jego własnością, wylewa się na ciało i zmysły ku sprawiedliwości i przynagla do pełnienia cnót ${ }^{116}$.

Taki jest opis nowego człowieka. Można wraz z o. Stefanem streścić całość jego wypowiedzi - nowy człowiek, to człowiek, który przyjął synostwo Boże, zyskał przyjaźń Boską, odnowił w sobie obraz i podobieństwo Boże przez życie łaską ${ }^{117}$. O. Stefan takiego człowieka nazywa żywą Ewangelią ${ }^{118}$. Wszystko to - stwierdza - dokonało się dzięki Chrystu-

111 Ćwiczenia Narodzenia, jw., k. 29. Takže: Jako mamy rodzić się z niego, jw., k. 42: „Człowiek nowy i wnętrzny najwięcej rad mieszka w części swojej najduchowniejszej na wierzchołku ducha istotności Boskiej, zapomniawszy samego siebie i wszystkiego świata gołą duszą patrzy na Boga".

112 Cwiczenia Narodzenia, jw., k. 31.

113 Co to jest dom Boży, Czerna AP rkps 246, s. 273-274. (Cyt. dalej: Dom Boży).

114 Jeruzalem, jw., k. 46; Cwiczenia Narodzenia, jw., k. 32.

115 .,(Bóg) mieszka w najwyższej części w pełności łaski przez wiarę gołą nad wszystek rozum, przez nadzieję bez rozumną wierząc w nadzieję... przez miłość gołą... zjednoczenie bez środka z Duchem Świętym, gdzie Boga przez Boga miłuje i dla samego Boga nie dla innych przyczyn, gdzie człowiek zostaje arcykapłanem do świątnicy wchodzącym Boga, Boga przez Boga chwalący, gdzie Bóg sam chwali samego siebie w człowieku" - Ćwiczenia Narodzenia, jw., k. 31v.

116 O wzięciu Ducha Swiętego, Czerna AP rkps 246, s. 262-267.

117 Cwiczenia Bożego Narodzenia, Wes rkps 62, k. 28.

118 ,Człowiek tedy chrześcijański z gruntu przez abnegację wyniszczony nic inszego nie jest tylko szczyra Ewangelia żywa, która w sobie zamyka Królestwo Boże, a Krzyżem Chrystusa dzieli się i broni od królestwa świata, czarta i ciała. (Tak) 
sowi, który ,stara się obraz Syna Bożego w nowym człowieku wymalować, wybić i udoskonalić... aż do wyrazu swego podobieństwa" ${ }^{119}$. Nowy człowiek więc, to osoba, w której mieszka sam Pan ${ }^{120}$.

\section{Cnoty}

O. Stefan podkreśla, że nowy człowiek wyraża tę nowość życia w dobrym i uporządkowanym życiu, w realizowaniu dobra, tzn. w życiu cnotliwym. Z tego życia wypływają konkretne zachowania się człowieka, czyli cnoty. Wiadomo, że istnieje wiele cnót. Zazwyczaj mistycy i poszczególni święci mieli swoje umiłowane cnoty, które stawały się podstawą ich duchowości. Na jakie cnoty kładzie nacisk o. Stefan? - Po krótkim zarysie pojęcia cnoty i jej przymiotów, szczegółowo opisuje takie zachowania się i cnoty jak: czystość serca, bojaźń Bożą, pokorę, posłuszeństwo i umiarkowanie ${ }^{121}$. Nadto krótko wspomina o milczącej samotności, zachowaniu przykazań oraz miłości wzajemnej.

\section{Przyobleczenie w Chrystusa}

Wzorcem nowego człowieka jest Chrystus Pan. On jest bowiem nowym człowiekiem i każdy, który pragnie się odnowić musi przyoblec się w Niego. O. Stefan właśnie temu tematowi poświęcił całe swoje nauczanie. Wszystkie jego pisma są ujęte pod kątem stawania się Chrystusem przez Jego naśladowanie. Szczególnie mówi o tym w swych rozważaniach opartych na roku liturgicznym ${ }^{122}$. Przede wszystkim zaś temu zagadnieniu poświęca traktat o doskonałym przyjmowaniu Komunii św. p.t. „Baranek Wielkanocny".

1. Podstawy przyoblekania się w nowego czlowieka

Chrystus - stwierdza o. Stefan - został dany człowiekowi jako Bóg i człowiek. W Nim człowiek zostaje w pełni odrodzony i w Nim otrzymał doskonały wzór swego człowieczeństwa. Cała praca nad przyobleczeniem się w nowego człowieka polega na kształtowaniu siebie według wzoru

rodzi się nowy człowiek, którego obraz pokazał nam Chrystus na sobie, wracając nas do oryginału, z któregośmy wyszli" - Praktyka abnegacji, jw., k. 31v.

119 Cwiczenia Bożego Narodzenia, jw., k. 27.

120 Jeruzalem, jw., k. 44, W innym miejscu podaje dwa sposoby przyjmowania na mieszkanie do siebie, mianowicie: przez miłość i dobre rozumienie o przyjmowanych oraz przez rady i cnoty doskonałe Chrystusa, np. miłość nieprzyjaciół. W ten sposób staje się człowiek podobny do Chrystusa (por. O trojakiej gubernacji, jw., s. 291).

121 Instrument, Czerna AP rkps 273, k. 20.

122 Zob. Wes rkps 62. Warto sobie przy tej okazji przypomnieć tytuły jego poszczególnych traktatów i konferencji - już one uświadamiają treść nauczania o. Stefana. 
Chrystusa, który ,obraz nászego oddania na sobie wyraził” ${ }^{123}$. O. Stefan pisze, dając przykład przyswajania sobie patrzenia Chrystusowego: „Oby oko nasze boskim było jako najpodobniejsze i bym mógł być poznany $\mathrm{z}$ oka..." 124 .

Chrystus Pan ukazuje siebie w Ewangelii. Ona też spełnia podstawową rolę w przeobrażaniu siebie, aż człowiek dojdzie do tego, by mówić ze św. Pawłem, że jest z Chrystusem przybity do krzyża oraz, że ,żyję już nie ja, lecz żyje we mnie Chrystus". By to się dokonało w człowieku, musi on jakby nieustannie „wychodzić z Boga”, inaczej mówiąc — wszystko rozpoczynać od Boga oraz nieustannie wracać do Boga, który jest początkiem i celem wszystkiego ${ }^{125}$.

O. Stefan ukazuje tajemnice życia i śmierci Chrystusa jako głębokie źródło życia wewnętrznego. „Każda tajemnica — pisze - przykład nam daje, aby każdy z tego wizerunku żył... aby w ten sposób ukazał się nowy człowiek jako z Boga wyszedł przez łaskę ukształtowany" ${ }^{126}$. Szczególną jednak uwagę zwraca na trzy największe tajemnice zbawienia ludzkiego. Zalicza do nich tajemnicę Wcielenia, tajemnicę Odkupienia oraz tajemnicę Zesłania Ducha Świętego. Stwierdza, że one „wyższym, szlachetniejszym, bardziej duchowym sposobem dzieją się w człowieku, i w duszy i w cielé". Dużo miejsca w całej jego działalności zajmuje przygotowanie do przeżywania tych tajemnic — świąt. Snuje też ciekawe refleksje w oparciu o czas trwania okresów liturgicznych ustanowionych przez Kościół na przygotowanie poszczególnych uroczystości, mianowicie: około trzydziestu dni przygotowania do przeżywania Bożego Narodzenia, czterdzieści dni przygotowania do Triduum Sacrum i pięćdziesiąt dni do Uroczystości Zesłania Ducha Świętego. W podobny także sposób rozwija treść swoich rozważań począwszy od nawiązania bliższego kontaktu z Bogiem w tajemnicy Wcielenia, aż do ,wzięcia Ducha Świętego do pełności za wypełnieniem pięćdziesiątnicy" ${ }^{127}$.

Jako kres życia człowieka ukazuje zmartwychwstanie z Chrystusem. Droga zaś do zmartwychwstania rozpoczyna się od wyrzeczenia się grzechu ciężkiego. Ten moment drogi nazywa o. Stefan ,,biednym początkiem żywota". Podaje więc drugą, bardziej odpowiednią drogę. Jest nią obumarcie z Chrystusem w duchu i dodaje, że ten właśnie sposób prowadzi do obcowania z Bogiem w niebie ${ }^{128}$.

${ }^{123}$ Exercita Adwentowe, jw., k. 36v.

124 Tamże, k. 31r.

125 Tamże, k. 31r.

126 Praktyka abnegacji, jw., k. 27r.

${ }^{127}$ Exercita Adwentowe, jw., k. 1; O wzięciu Ducha Sw., jw., k. 63-64.

128 Jako mamy zmartwychwstawać. Czerna AP rkps 246, s. 250-257. Pisząc o zachowaniu ślubów, podaje dwa sposoby życia według nich. Pierwszy: „do zbawienia samego tylko", drugi: „według naśladowania Chrystusa”. Przy tym dodaje: „Nie 
Pisząc zaś o przyjmowaniu Komunii św. powiada, że w tym sakramencie człowiek zażywa tego samego dobra co Bóg, mianowicie: jeśli w sposób pełny przyjmuje Jezusa, tzn. stara się w Niego przeobrazić, wchodzi w kontemplację prawdy oraz miłości Bóstwa i Człowieczeństwa, przeżywa świętych obcowanie, gdyż tego samego Chrystusa wszyscy przyjmują i z tym samym Chrystusem się jednoczą; Chrystus który jest życiem, staje się własnością człowieka - jest danym człowiekowi ${ }^{129}$.

\section{Naśladowanie Chrystusa}

Chrystus po to przyszedł na świat - stwierdza o. Stefan - aby człowiek z samego Boga się narodził i z Chrystusa, czyli by człowiek obraz Boży w sobie odnalazł i ugruntował. To działanie odnowcze rozpoczyna w człowieku sam Bóg przez łaskę Chrztu św. ${ }^{130} \mathrm{Kształtuje} \mathrm{się} \mathrm{zaś} \mathrm{ten} \mathrm{ob-}$ raz Boży Chrystusa ,przez żywe barwy naśladowania jego” ${ }^{131}$. Naśladowanie więc Chrystusa prowadzi do ukształtowania w sobie obrazu Bożego.

Jak o. Stefan w praktyce ustawia naśladowanie? Autor przykładowo podaje naśladowanie Chrystusa w wyrzeczeniu. Przy tej okazji powiada, że naśladowanie Chrystusa z serca człowieka wyrzuca starego człowieka. Uroczystość Trzech Króli, powinna skłaniać człowieka do pójścia wraz z Królami do Chrystusa drogą wiary i woli Bożej przez zaciemnienie swego rozumu, pamięci, własnego zdania i woli. Maleńki Jezus uczy pokory, ukrycia; dwunastoletni Jezus słucha i pyta w świątyni doktorów, oraz uczy by być w rzeczach, które do Ojca należą... itd. ${ }^{132}$ O. Stefan, jak widać, jest bardzo konkretny i podaje konkretne zachowania. Przede wszystkim proponuje rozważanie Słowa Bożego oraz wpatrywanie się w Chrystusa. Na pewno nie chodzi mu jedynie o zewnętrzne naśladowanie. Wyraziście mówi o wewnętrznym naśladowaniu i wewnętrznym upodobnieniu, np. w traktacie „O pożytku z Męki Pańskiej” napisze o potrójnym rozważaniu tej tajemnicy - a) zewnętrznym i historycznym, który jednak sposób jest mało pożyteczny, gdyż słabo angażuje człowieka, — b) o naśladowaniu zewnętrznych cnót Chrystusa oraz trosce, by niczego

każdy koń, choć koniem, dowiezie do Rzymu" - Sposób ćwiczenia duchowego, jw., k. 4.

${ }^{129}$ Baranek Wielkanocny, jw., k. 85r.; O jednoczeniu się $z$ drugimi przez Eucharystie pisze: „A tego zbyt sytego Chleba, tej jedności i społeczności godzi się nam zażywać jeszcze w tym Sakramencie, którym się wszyscy jednoczymy i jedno stajemy. Bo ten Sakrament Ciała Pańskiego biorę ja, Piotr, Jan... i wszyscy, którym się ciałem jednoczymy i w jedno Ciało Pańskie zlewamy, stając się mu wczłonkowani $i$ on sam. Tegoż Chrystusa zażywa Piotr w Janie, a Jan także w Piotrze i widza się jedno tymże Chrystusem; tegoż Chrystusa obaj w sobie miłują i kontemplują... Skąd też ten Sakrament zowie się w jedności i miłości wszystko w jedno zlewający" - tamże.

130 Cwiczenia Bożego Narodzenia, jw., k. 36r: „Bóg sam poczyna tablice do swego obrazu stworzoną przez chrzest św. malować".

${ }_{131}$ Tamże, k. $36 \mathrm{r}$.

132 Praktyka abnegacji, jw., k. 27v. 
Bogu nie odmówić, - c) o naśladowaniu Chrystusa według Jego cnót wewnętrznych, tzn. jak Chrystus zachowywał się wobec Ojca, wobec siebie samego, wobec uczniów i innych... ${ }^{133}$ Podaje przy tym bardzo konkretne przykłady: zachowanie Chrystusa wobec Judasza, czy przyjmowanie wszystkiego (szczególnie w Ogrojcu) z ręki Ojca ${ }^{134}$. Sporo miejsca w swych rozważaniach autor poświęca Męce Chrystusa i naśladowaniu Go w Jego Męce, urabianiu siebie przez przeżywanie Męki, zwłaszcza według trzeciego sposobu rozważania. Kiedy omawia tajemnicę zmartwychwstania naszego z Panem, pisze: „Kto z Chrystusem mękę Jego przez naśladowanie odprawi... zmartwychwstanie" ${ }^{135}$. By zaś zmartwychwstać i oblec się w nieśmiertelność, ,człowiek stary i powierzchowny na krzyżu zawsze powinien wisieć" ${ }^{136}$. Ciekawie także autor-komentuje słowa św. Pawła: „wszyscy zmartwychwstaniemy, nie wszyscy będziemy przemienieni", podkreślając, że właśnie o tę przemianę obecnie chodzi. Ona dokonuje się przez naśladowanie Chrystusa ${ }^{137}$.

W „Baranku Wielkanocnym” prawie wyłącznie zajmuje się naśladowaniem Chrystusa, aż do całkowitego z Nim zespolenia. Bardzo szczegółowo omawia to zagadnienie, opisując prawdziwe spożywanie - przyjmowanie Chrystusa w Komunii św. Ciało Chrystusa dzieli - podobnie jak i nasze ciało - na dwanaście cząstek. Można by w nich widzieć dwanaście stopni przeobrażenia się w Chrystusa. Całość zagadnienia omawia w czterech częściach. Zaczyna od zmysłów zewnętrznych i wewnętrznych, poprzez uczucia aż do przyjmowania Chrystusa duszą i duchem, czyli aż do pełnego przeobrażenia się w Chrystusa. Całość wypowiedzi jest niezwykle zwięzła i bogata, a zarazem wydaje się, że dla przedstawienia jego sposobu myślenia, wystarczy podkreślić myśl główną, np.: przy przyjmowaniu Chrystusa zmysłami zaznacza - ,by zmysły nasze były jako Chrystusowe" ${ }^{138}$. O. Stefanowi chodzi więc przede wszystkim o dyspozycję wewnętrzną, gotowość i umiłowanie, by nie przyjmować Chrystusa tylko zewnętrznie, jakby tylko ustami, lecz by dać się przeniknąc Chrystusowi, którego się przyjmuje. W jego ujęciu przyjąć oznacza — stać się jak Chrystus.

W tym naśladowaniu Chrystusa idzie tak daleko, że na przykład stawia takie wymagania: „Mamy usiłować naśladować Chrystusa jak błogosławieni w niebie; aktem wiary gołej i żywej przez wpatrywanie się w Niego" ${ }^{139}$. Oczywiście nie chce powiedzieć, że święci w niebie żyją wiarą.

${ }^{133}$ O trojakim pożytku z Męki Pańskiej, Wes rkps 62, k. 52-54.

134 Tamże, k. 54: „Druga cnota wewnętrzna Chrystusa że On wszystkie męki swoje i zelżywości... z rąk Ojca i miłości Jego niezmiernej ojcowskiej i z tak wielką chęcią Jego przyjmował".

${ }_{135}$ Jako mamy zmartwychwstać, jw., k. 56v.

136 Tamże, k. 58.

137 Tamże, k. 57.

138 Baranek Wielkanocny, jw., k. 86v. 
Chodzi autorowi o to, że tu na ziemi można to czynić aktem żywej i czystej wiary. Od tego momentu zaczyna się dopiero prawdziwe życie, o którym ,jeden ze zmartwychwstałych (zjednoczonych) — powiedział: „Któż nas oderwie od miłości Bożej" ${ }^{140}$.

Jeszcze raz wraca o. Stefan do tego tematu w traktacie: „Jako w nas Chrystus wchodzi od wschodu $i$ zachodu". Trudno ustalić kryteria, które skłoniły go do takiego nazwania - chodzi o dwa sposoby przeobrażenia się w Chrystusa - wejścia Chrystusa od zachodu wejściem z w y c z a jn y m i dłuższym, tzn. sposobem opisanym w ,Baranku Wielkanocnym". Obejmuje on okres życia duchowego od oczyszczenia zmysłów aż do uformowania swego ducha na wzór Chrystusa ${ }^{141}$. Droga ta jest długa i uciążliwa. Drugie wejście zaś Chrystusa od wschodu nazwał n a d z w yc z a jnym. Może podstawą podziału było samo słońce. W pierwszym wypadku właśnie ono zaszło. Zanim w swym biegu dojdzie poprzez noc do brzasku dnia, upłynie wiele czasu. Człowiek tą drogą idący do Boga; przechodzi przez oczyszczające noce i wiele utrapień. Taka jest zwyczajna droga człowieka. Wejście zaś Chrystusa od wschodu jest jak nagłe rozbłyśnięcie słońca. Człowiek sposobem nadzwyczajnym — pisze o. Stefan - dotyka P. Boga w najwyższej części ducha i dotyk ten bardzo go ożywia. Sam Bóg daje się człowiekowi, udzielając mu wraz z łaską cnót wlanych, darów Ducha Świętego i Jego owoców. Wprawdzie i wtedy człowiek musi przejść przez oczyszczenia, lecz podejmuje je przynaglany pełnią Boga, którą otrzymał ${ }^{142}$.

W pierwszym wypadku - wchodzenie Chrystusa od zachodu - przyoblekanie się w Chrystusa dokonywałoby się przez systematyczną pracę nad sobą i urabianie całego siebie na Jego wzór w sposób podany wyżej. W drugim wypadku sam Bóg bierze w posiadanie człowieka i wszystkie władze jemu się przyporządkowują. Można by więc mówić o naśladowaniu Chrystusa czynnym oraz o naśladowaniu Chrystusa biernym czy lepiej receptywnym.

Ponieważ Bóg obdarzył człowieka wolnością, w każdym wypadku trzeba pracy i wysiłku człowieka, aby Chrystus mógł w nim zamieszkać. Dlatego też Chrystusa bierze człowiek w swe posiadanie i panuje w Jego sercu w zależności od tego czy całkowicie, czy też częściowo poddaje siebie albo swoje rzeczy Bogu ${ }^{143}$. Stopień więc przyobleczenia się w Chrystusa jest uzależniony od człowieka.

Człowiek zatem staje się nowym człowiekiem przez naśladowanie

139 Tamże, k. $101 \mathrm{v}$. $60 \mathrm{r}$.

140 Po zmartwychwstaniu $z$ Chrystusem do wniebowstapienia, Wes rkps $62, \mathrm{k}$.

141 Jako $w$ nas Chrystus wchodzi, Wes rkps 62, k. 71.

142 Tamże, k. 74.

143 O trojakiej gubernacji, jw., s. 280. 
Chrystusa - Nowego Człowieka. Naśladowanie to polega na wewnętrznym upodobnieniu się do Chrystusa. Jest to więc wyraźny Chrystoformizm. Tylko na pierwszy rzut oka nauka o. Stefana wydaje się być Chrystocentryczna. Rzeczywiście Chrystus jest ośrodkiem całej działalności człowieka, ośrodkiem pracy nad sobą. Niemniej naśladowanie Chrystusa prowadzi w Duchu Swwiętym i przez pośrednictwo Kościoła do zjednoczenia z Bogiem w Trójcy Jedynym ${ }^{144}$.

$\mathrm{Na}$ zakończenie tej części pracy, dotyczącej zarysu nauki głoszonej przez o. Stefana, warto podkreślić, że główną treścią jego działalności piśmienniczej i duszpasterskiej było życie mistyczne. Wszystkie jego wypowiedzi są wyraziście ukierunkowane na zjednoczenie z Bogiem. Niewątpliwie wpłynęła na to jego przynależność do Zakonu Karmelitów Bosych oraz objęcie swą pracą duszpasterską szczególnie karmelitanek bosych, dla których w pierwszym rzędzie pisze i głosi konferencje. One zaś prowadziły tryb życia ściśle kontemplacyjny i wiele $\mathrm{z}$ nich było kontemplatyczkami.

Konsekwencją tego uwarunkowania autora jest podkreślenie potrzeby całkowitego oczyszczenia - wyrzeczenia starego człowieka oraz cała pozytywna nauka na temat przeobrażenia się wewnętrznego na wzór Jezusa Chrystusa, i przez przyjęcie Jego sposobu życia stanie się nowym człowiekiem. Szczególną rolę w tym przyoblekaniu się w Chrystusa autor widzi w nabożeństwie do Męki Pańskiej oraz w doskonałym przyjmowaniu Jezusa w Eucharystii.

Swoje rozważania o. Stefan w przeważającej części opiera na roku liturgicznym, prowadzącym do zjednoczenia przez kontemplację tajemnicy Wcielenia i Odkupienia.

\section{LA PRATIQUE DE LA VIE SPIRITUELLE SELON P. ETIENNE KUCHARSKI} $(1595-1653)$

Rés u mé

Le Père Etienne de sainte Thérèse Kucharsiki, carme déchaux — polonnais (1595-1653) nous apparaît dans toute son activité en tant qu'un mistique. La pratique de sa vie spirituelle comprend deux courants se pénétrant mutuellement: la renonciation au vieil homme et le revêtement de l'homme nouveau.

${ }_{144}$ Exercita Adwentowe, jw., k. 1-2; Baranek Wielkanocny, jw., k. 144-145. Pisze tam w zakończeniu: „Ta jest drabina bogomyślnego Jakuba z Człowieczeństwa Chrystusowego złożona... a iż ułomności naszej ciężko bardzo i trudno w górę, ten Sakrament Najświętszy uczynił się nam drabiną, oczyścił nas i uwolnił $\mathrm{z}$ ciężarów, podał ręce i posiłek pokarmowy, żebyśmy za tym Barankiem mogli wstępować po szczeblach i przyjść aż do Ojca wspartego na wierzchołku tej drabiny, którą jest sam Chrystus. Droga, Prawda i Żywot" (tamże). 
Il entend par vieil homme: les sept péchés capitaux enracinés dans l'homme avec les vices qui en proviennent; tout ce qui n'est pas Dieu et ne mène pas à Dieu. De là, la nécessité de la purification jusqu'à ,l'expulsion du vieil homme pour que le Christ puisse naître en lui". À la base de cette renonciation se trouve le désir de Dieu et la conscience de ses propres défauts. Sans cela l'homme n'arrivera pas à son innocence primitive. L'accepter de la croix, se renoncer, tout abandonner, crucifier du vieil homme, vendre tout sont les moyens pour arriver à la puretẹ du coeur. L'homme peut tenter de se renoncer de deux manières: en observant uniquement les commandementes ou bien en suivant la voie des conseils: l'amour, la pauvreté, l'obéissance; chaque fois qu'il s'agit de soumission totale à la volonté de Dieu, pour qu'il puisse intervenir en l'homme comme Il le veut. La méditation de la passion du Christ est la meilleure façon de renoncer rapidement à soi.

Ensuite, le Père Etienne nous transmet unique de la conduite de l'homme"; dans les deux règles de la renouciation: „pour que Dieu soit cause ce but il faut anéantir en soi l'honneur du corps, les richesses du corps et les plaisirs du corps. De même il faut renoncer à l'honneur de l'esprit, aux richesses de l'esprit et aux plaisirs de l'esprit. Ensuite, il met en relief le besoin de la purification de l'âme et il exige la destruction de l'honneur des biens temporels, de la richesse spirituelle et des plaisirs spirituels. De cette façon l'homme doit prendre conscience qu'il n'est rien, qu'il n'a rien, qu'il ne sait rien, qu'il ne peut rien de soi-même, mais tout ce qu'il a, lui vient de Dieu".

A part cette conception négative du travail envers soi-même, P. Etienne trace l'image de l'homme nouveau, image inséparable de la première. Adam, et encore plus le Christ sont l'image de l'homme nouveau. À la base de ces modèles, on pourrait définir l'homme nouveau de cette façon: l'homme nouveau est un homme au coeur pur, c'est un homme rangé et pensant à Dieu, c'est un homme qui retrouve Dieu en soi-même et L'éprouve. Le fondament de l'homme nouveau est Dieu présent en lui. A part la présence naturelle, P. Etienne écrit de la, présence de Dieu en l'homme à travers la grâce, la fréquentation, la connaissance claire et à travers l'amour - comme celui qui est aimé en celui qui aime. Dieu rend l'homme capable de cette union à Lui. Lorsque l'homme reçoit Dieu, Dieu peut embrasser „le sommet de l'esprit" et demeurer en lui - dans ses sens, sentiments et facultés de l'esprit. Tout cela accomplit grâce au Christ. Puisque le Christ est le modèle de l'homme nouveau et tout homme qui désire se renouveler, doit Le revêtir.

L'auteur nous montre le revêtement de Christ à la base du contact avec Dieu dans le mystère de l'Incarnation jusqu'à ,la réception de l'Esprit Saint dans la plénitude de la Pentecôte". En écrivant de 'l'imitation du Christ il met en relief lá nécessité de l'assimilation des orientations intérieures et de Ses inclinations. C'est à la Communion qu'il atribue le rôle particulier dans comportement envers le Christ. Dans sa conception, recevoir le Christ veut dire Le devenir. P. Etienne apelle l'homme nouveau l'Evangile vivant. Une telle imitation conduit au Saint-Esprit, par l'initermediare de l'Eglise, à l'union en un Seul Dieu idans la Trinité. 